\title{
Dragonflies and damselflies of the St Katherine Protectorate
}

\author{
Andrew Power* \& Francis Gilbert
}

School of Life Sciences, University of Nottingham, Nottingham NG7 2RD, UK

\begin{abstract}
The indigenous Bedouin tribes of South Sinai (Egypt) irrigate small gardens for agricultural purposes and this has been shown to boost the biodiversity of plants, birds and insects, including dragonflies (Odonata). The gardens offer water-related resources normally in short supply in arid regions. There is very little information available on the dragonflies and damselflies of the Sinai. We assess the importance of Bedouin gardens to Odonata by recording them in the gardens and in unmanaged habitat in the St Katherine Protectorate. The gardens are widely utilised by Odonata: ten species were recorded in total, all observed in the gardens at least once.
\end{abstract}

\section{Introduction}

The Odonata of Egypt has received remarkably little attention (Boudot et al., 2009), and in particular very few records exist for the Sinai and the high mountains of the St Katherine Protectorate and most of these are old. More recent studies have concentrated on the Nile valley and in the Western Desert (Dijkstra \& Boudot, 2010) and highlight the need for further research on the Odonata of Egypt. The St Katherine Protectorate is one of the wettest places in Egypt, a biodiversity hotspot and so is likely to provide habitat for arid-adapted odonate fauna. The IUCN have declared the area as one of the most important centres for plant diversity in the Middle East (Grainger \& Gilbert, 2008). The area is also important for insects; two-thirds of the butterfly species found in Egypt have been recorded in the St Katherine Protectorate (Gilbert \& Zalat, 2007). A mixture of European, African and Asian species can be found in this region because of its unique position between continents. The importance of the St Katherine Protectorate to Odonata is largely unknown.

There is a comparatively high amount of water available in the Sinai. On average the area receives $62 \mathrm{~mm}$ of rainfall a year (Zahran \& Willis, 2009). The high mountains are sometimes covered in snow during the winter, and slow snow melt ensures the aquifers have water throughout the rest of the year (Grainger, 2003). Areas with a higher rainfall tend to have higher odonate species diversity than areas with lower rainfall (Suhling, 2009). Open water sources are essential for Odonata to breed and are also important for feeding. The indigenous Bedouin people harvest rainwater to irrigate their gardens for their orchard agriculture, shown to boost plant diversity to higher levels than found in wild unmanaged habitat (Norfolk et al., 2012). This in turn benefits insect and bird communities that take advantage of the increased amount of food, water and shelter available (Norfolk et al., 2014). Traditional agricultural practices may also benefit dragonfly and damselfly populations. In many Bedouin gardens, harvested rainwater is stored in open wells which are utilised by Odonata as breeding habitats and for feeding. Intensive agriculture in Europe has resulted in the massive loss of natural aquatic ecosystems, but the construction of irrigation pools and reservoirs for irrigation provides replacement habitat for aquatic invertebrates (Abellán et al., 2006) and aquatic plants (Oertli et al., 2002). Artificial irrigation ponds and wells vary greatly in their design (Wisser et $a l ., 2010)$ and this may affect the abundance of invertebrates and vegetation. The pools and reservoirs referred to in these studies are much larger than the wells found in Bedouin gardens but the effect on the biodiversity of aquatic life is likely to be positive. It is also possible the Bedouin gardens have a negative impact on Odonata because the harvested rainwater may reduce the amount of water available to the already limited naturally occurring pools: irrigation

* Author for correspondence: email :powera2@tcd.ie 
of arid land for agricultural purposes requires significant amounts of water resources (Peiró, 1996).

The purpose of this study is to see if traditional Bedouin gardens are utilised by odonate populations and to see what species occur in the St Katherine Protectorate.

\section{Materials \& Methods}

In the summer of 2012 the rare endemic butterfly the Sinai Hairstreak Satyrium jebelia was studied for the first time (Power et al. 2015). The butterfly has a small range and persists in a series of interconnecting wadis and on the mountain slopes of the Saint Katherine Protectorate. The study took place between the $15^{\text {th }}$ of April and the $15^{\text {th }}$ of August. The majority of this period was either spent within unmanaged natural habitats of the Protectorate, where the butterfly was present, or in the Bedouin gardens. The location and habitat type was noted for every Odonata species recorded. Odonata were caught using a large butterfly net when possible and photographed before release for identification purposes. The habitat in which they were observed was categorised as unmanaged habitat or gardens. Areas irrigated for agricultural purposes by the Bedouin were classified as gardens. Areas that were not irrigated and free of human habitation were classified as unmanaged habitat. The presence of wells and other water resources was noted in both habitat types.

\section{Results}

Wandering Glider Pantala flavescens

One of the most widely distributed dragonfly species on the planet and has well-known migratory species. It is listed as a vagrant species to Egypt (IUCN) and is a rare species in Europe and North Africa. A single male was seen in in Wadi Ahmar on the $17^{\text {th }}$ of July and in the Fox Camp garden in the town of St Katherine on the $25^{\text {th }}$ of July. There are few records of this species in the Sinai.

\section{Broad Scarlet Crocothemis erythraea}

This is a common species in Southern Europe and North Africa with several records for the Sinai. A female was seen in Jebel Bab on the $8^{\text {th }}$ of July and in Wadi Ahmar on the $17^{\text {th }}$ of July. One male was seen in Wadi Matter on the $14^{\text {th }}$ and the $17^{\text {th }}$ of July. Dragonfly activity was high around the pools and there may have been more than one individual present.

\section{Vagrant Emperor Anax ephippiger}

A species native to Egypt and the Sinai (IUCN), the Vagrant Emperor is an obligate migrant. As many as six Vagrant Emperors were seen between the well-vegetated Wadi Ahmar and Wadi Matter on the $14^{\text {th }}, 17^{\text {th }}$ and $27^{\text {th }}$ of July. Many of these individuals appeared to be patrolling territories.

\section{Lesser Emperor Anax parthenope}

This species is native to mainland Egypt (IUCN) with some records from the Sinai. One individual was seen in Fox Camp, St Katherine on the $23^{\text {rd }}$ of June. It was caught in an outdoor lamp in the camp.

\section{Red-veined Dropwing Trithemis arteriosa}

A widespread and common afrotropical species (Boudot et al., 2009) that is native to Egypt and the Sinai (IUCN). There are several records from the St Katherine Protectorate. A male 
was seen in a Bedouin Garden in Wadi Jebel on the $18^{\text {th }}$ of April, in a Bedouin Garden next to an open well in Wadi Itlah on the $23^{\text {rd }}$ of April, and in Wadi Matter on the $17^{\text {th }}$ and $28^{\text {th }}$ of July. A single female was seen between Wadi Albein and Jebel Ahmar on the $29^{\text {th }}$ of May, in a Bedouin Garden in Wadi El-Freya on the 31st of May, in a garden in Abu Teenya near an exposed well on the $24^{\text {th }}$ of June and in Wadi Matter on the $14^{\text {th }}$ of July.

\begin{tabular}{lccc}
\hline \multirow{2}{*}{ Species } & \multicolumn{3}{c}{ Sightings } \\
\cline { 2 - 4 } & gardens & $\begin{array}{l}\text { wild } \\
\text { habitat }\end{array}$ & Total \\
\hline Wandering Glider Pantala flavescens & 1 & 1 & 2 \\
Broad Scarlet Crocothemis erythraea & 1 & 2 & 3 \\
Vagrant Emperor Anax ephippiger & 3 & 3 & 6 \\
Lesser Emperor Anax parthenope & 1 & 0 & 1 \\
Red-veined Dropwing Trithemis arteriosa & 6 & 1 & 7 \\
Red-veined Darter Sympetrum fonscolombii & 2 & 1 & 3 \\
Southern Skimmer Orthetrum brunneum & 5 & 0 & 5 \\
Ransonnet's Skimmer Orthetrum ransonnetii & 2 & 0 & 2 \\
Epaulet Skimmer Orthetrum chrysostigma & 1 & 0 & 1 \\
Evan's Bluetail Ischnura evansi & 5 & 0 & 5 \\
Unidentified species & 1 & 1 & 2 \\
\hline Total & 28 & 9 & 37 \\
\hline
\end{tabular}

Table 1: Odonata species observed showing number of sightings and location

\section{Red-veined Darter Sympetrum fonscolombii}

This species is native to Egypt and the Sinai. It is widespread in southern Europe and Africa. A male and a female were seen in Wadi Matter on the $29^{\text {th }}$ of July and a female was seen in Jebel Bab on the $9^{\text {th }}$ of August. Most records for the St Katherine Protectorate and the South Sinai are from before 1980 (Boudot et al., 2009).

\section{Southern Skimmer Orthetrum brunneum}

This species is common and widespread in Europe but is considered rare in North Africa. There are only two, probably old, records available from the Sinai (Dumont, 1991). Up to five individuals were seen in Wadi Matter on the $14^{\text {th }}, 17^{\text {th }}$ and the $28^{\text {th }}$ of July.

\section{Desert Skimmer, Ransonnet's Skimmer Orthetrum ransonnetii}

A desert-dwelling species that is resident to Egypt and the Sinai. One individual was seen in a Bedouin garden next to open well in Wadi Itlah on the $23^{\text {rd }}$ of April. One female was seen in Fox Camp, St Katherine on the $2^{\text {nd }}$ of August.

\section{Epaulet Skimmer Orthetrum chrysostigma}

This is a resident species in Egypt and Sinai with several records from the St Katherine Protectorate. One female was seen in Abu Towaita in a Bedouin Garden on the $26^{\text {th }}$ of June.

\section{Evan's Bluetail Ischnura evansi}

This species is listed as native to mainland Egypt and the Sinai (IUCN). This was the only adult damselfly species recorded during the study and there are some previous records of the species in the Sinai. Over five individuals (males and females) were seen in Wadi Matter on the $14^{\text {th }}, 17^{\text {th }}$ and $28^{\text {th }}$ of July. 


\section{Unidentified species}

A female Orthetrum species was observed in Wadi Matter on the14th of July, most likely Orthetrum brunneum or Orthetrum coerulescens (which was not otherwise positively identified during the study period). A damselfly was observed emerging from the main pool at Galt Al Azraq on the $11^{\text {th }}$ of August. Due to the difficulty in identifying newly emerged species it could not be identified. It was most likely a Pseudagrion species, based on the striated appearance of the eyes (Jean-Pierre Boudot, pers. comm.).

\section{Discussion}

Our results show that the Bedouin gardens are important and widely utilised by Odonata species in the region. Ten species were recorded in total and all of them were observed in the Bedouin gardens at least once. Most Bedouin gardens have an open exposed well and some of the more irrigated gardens contain additional water storage units and pools. Odonata have been shown quickly to take advantage and colonise artificial water pools (McCauley et al., 2010). Some desert-dwelling species have only ever been recorded breeding in artificial pools, thus demonstrating the value of these newly created ecological conditions to colonising Odonata (Borisov, 2006). For some species the newly created habitat is more favourable than the original habitat (Borisov, 2006). The St Katherine Protectorate has no rivers, canals or lakes, and virtually all water is found in small naturally occurring pools and in Bedouin wells. In arid regions the number of artificial reservoirs in arid regions can outnumber natural water reservoirs (Borisov, 2006). The Bedouin gardens provide new habitat for colonising Odonata.

The Southern Skimmer was recorded for only the third time in the Sinai (Dumont, 1991) in this study. At least five individuals were observed at the same pool in Watter Matter on three occasions in July. It is common in parts of Southern Europe and the Mediterranean and there are recent records from the Levant in Israel and Lebanon. This study indicates that breeding populations of the Southern Skimmer may exist in the Sinai but further surveys are needed to confirm this. More information is required on the odonate fauna of the Sinai and the St Katherine Protectorate because many of the species recorded in this study have fewer than ten records for the region.

The Bedouin wells and pools provide food and breeding habitat for Odonata. Adult Odonata have two main strategies for catching prey, hawking and gleaning. Hawking involves catching prey in mid-air while in flight, and they can either patrol for food or perch on prominent vegetation waiting for suitable prey to fly past. Gleaning involves hovering over and seizing prey perched on vegetation. Water sources attract invertebrates and provide abundant prey for Odonata species. Some Bedouin use small exposed concrete wells with no vegetation or obvious aquatic invertebrate life to store drinking water. Odonata were observed feeding and perching around these water sources.

Many of the wells provided suitable breeding habitat for Odonata. Water is essential for dragonfly reproduction; females lay their eggs in the water or on vegetation depending on the species. The aquatic larva that emerges is predatory and feeds on aquatic invertebrates. Bedouin wells with aquatic plant life and vegetation bordering the edges provide ideal breeding habitat for Odonata. Artificial irrigation ponds can be biodiversity hotspots for aquatic invertebrates providing food for larval Odonata species. The Bedouin use these wells to irrigate the crops in their gardens. Emerging damselflies and dragonflies were observed in a Bedouin garden in Wadi Matter and in a natural pool in Galt Al Azraq (the Blue Pool). The most prolific site for Odonata observed during this study was in a Bedouin garden in Wadi Matter. All observations occurred around well-vegetated pools situated around a main well. It was difficult to determine if the pools were natural or as a result of spill over from harvested water from the main well. Galt Al Azraq is a true oasis and was the largest natural pool 
encountered in this study: it appeared to be perfect habitat for Odonata. The site is famous and is known as one of the largest natural occurring water sources in the region, present all year round (Zalat \& Gilbert, 1998). Galt Al Azraq was only briefly visited and is an ideal site for future study.

Without long-term data it is difficult to determine if there is more or less habitat available to Odonata as a result of Bedouin agricultural practices. The water available to naturally occurring pools may be limited by Bedouin farming practices and the increasing water demands in the town of St Katherine (Abdulla et al., 2003). Bedouin farmers may initially have selected areas with high water availability to cultivate their gardens so the locations of historical naturally occurring pools and Bedouin gardens may be similar. It is likely the Bedouin gardens take on an added importance to Odonata in the dry summer months. Much of the rainwater harvested by the Bedouin would be lost naturally and the Bedouin gardens may provide habitat to Odonata that would not exist in natural conditions. Regardless of the impact of Bedouin agriculture on naturally occurring water sources in the St Katherine Protectorate, it is clear from this study that they are currently very important to Odonata species. According to global warming predictions the Sinai will become hotter and drier in the future, and hence the Bedouin gardens may become essential for helping maintain the biodiversity of the region.

\section{Acknowledgements}

We thank the Egyptian Environmental Affairs Agency and Mr Mohamed Qotb, manager of the St Katherine Protectorate, for permission to do the work; Dr Brian Nelson, Dr Jean-Pierre Boudot and Dr Klaas-Douwe Dijkstra for help with Odonata identification. We are grateful to our expert local Bedouin guides Nasr Mansour and Suleiman Abusada. We thank Olivia Norfolk, Lisa Gecchele, Brian Power, Peter Cutler, Féaron Cassidy, Luke McLeod and Katy Thompson for field support and companionship and everyone at Fox Camp for logistical help.

\section{References}

Abdulla H, Ghodeif K, El-Shatoury S \& Dewedar A (2003) Potential contamination of groundwater in the World Heritage Site of the St. Katherine Protectorate, Egypt. Egyptian Journal of Biology 5: 1-9

Abellán P, Sánchez-Fernández D, Millán A, Botella F, Sánchez-Zapata JA \& Giménez A (2006) Irrigation pools as macroinvertebrate habitat in a semi-arid agricultural landscape (SE Spain). Journal of Arid Environments 67(2): 255-269

Boudot J-P, Kalkman VJ, Azpilicuenta Amorín M, Bogdanović T, Cordero Rivera A, Degabriele G, Dommanget J-L, Ferreira S, Garrigós M, Jovic M, Kotarac M, Lopau W, Marinov M, Mihokovic N, Riservato E, Samraoui B \& Schneider W (2009) Atlas of the Odonata of the Mediterranean and North Africa. LibellulaSupplement 9: 1-256

Borisov SN (2006) Adaptations of dragonflies (Odonata) under desert conditions. Entomological Review 86(5): 534-543

Dijkstra KDB \& Boudot J-P (2010) First update of the Atlas of the Odonata of the Mediterranean and North Africa: Orthetrum machadoi new to the Palaearctic and Agriocnemis sania new to the Egyptian Nile Valley. Libellula-Supplement 29: 107-125

Dumont HJ (1991) Fauna Palaestina. Insecta V. Odonata of the Levant. The Israel Academy of Sciences and Humanities, Jerusalem

Gilbert F \& Zalat S (2007) Butterflies of Egypt: atlas, Red Data listing \& conservation. EEAA, Cairo, Arab Republic of Egypt

Grainger J (2003) 'People are living in the park' - linking biodiversity conservation to community development in the Middle East region: a case study from the Saint Katherine Protectorate, Southern Sinai. Journal of Arid Environments 54: 29-38

Grainger J, Gilbert F (2008) Around the sacred mountain: the St Katherine Protectorate in South Sinai, Egypt. Protected Landscapes \& Cultural \& Spiritual Values. Values of Protected Landscapes \& Seascapes 2: 2137. IUCN, Kasparek Verlag, Heidelberg.

IUCN (2014) The IUCN Red List of Threatened Species [Online]. http://www.iucnredlist.org

McCauley SJ, Brodin T \& Hammond J (2010) Foraging rates of larval dragonfly colonists are positively related to habitat isolation: results from a landscape-level experiment. American Naturalist 175(3): E66-E73 
Norfolk O, Abdel-Dayem M \& Gilbert F (2012) Rainwater harvesting and arthropod biodiversity within an arid agro-ecosystem. Agriculture, Ecosystems \& Environment 162: 8-14

Norfolk, O, Power A, Eichhorn MP \& Gilbert F (2015). Migratory bird species benefit from traditional agricultural gardens in arid South Sinai. Journal of Arid Environments 114: 110-115.

Oertli B, Joye DA, Castella E, Juge R, Cambin D \& Lachavanne JB (2002). Does size matter? The relationship between pond area and biodiversity. Biological Conservation 104(1): 59-70

Peiró V, Sánchez-Zapata JA, Ferrández T \& Martínez M (1996) La comunidad de aves acuáticas de embalse y zonas colindantes del sur de la provincia de Alicante. Instituto de Estudios Juan Gil-Albert. Universidad de Alicante. Alicante

Power A, Zalat S \& Gilbert F (2014) Nowhere left to go: the Sinai Hairstreak Satyrium jebelia. Journal of Insect Conservation 18: 1017-25

Suhling F, Samways MJ, Simaika JP \& Kipping J (2009) Status and distribution of the Odonata in Southern Africa:. In: Darwall WRT, Tweddle D, Skelton P, Smith K (Eds.). The status and distribution of freshwater biodiversity of southern Africa. IUCN, Gland, Switzerland and Cambridge, UK. pp. 48-65

Wisser D, Frolking S, Douglas EM, Fekete BM, Schumann AH \& Vörösmarty CJ (2010) The significance of local water resources captured in small reservoirs for crop production - a global-scale analysis. Journal of Hydrology 384(3): 264-275

Zahran MA \& Willis A J (2009) The Sinai Peninsula. pp 213-249 in The Vegetation of Egypt. Springer Science.

Zalat S \& Gilbert F (1998). A walk in Sinai: St Katherine to Al Galt Al Azraq (The Blue Pool). Egyptian Journal of Natural History 1(1): 1-66

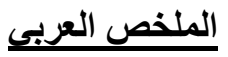

